Abstracta Iranica Abstanica

Revue bibliographique pour le domaine irano-aryen

Volume 32-33 | 2013

Comptes rendus des publications de 2009-2010

\title{
Mansour Bonakdarian. Iranian Studies in the United Kingdom in the Twentieth Century
}

Laetitia Nanquette (Bif)

\section{OpenEdition}

1 Journals

\section{Édition électronique}

URL : http://journals.openedition.org/abstractairanica/40969

DOI : 10.4000/abstractairanica.40969

ISSN : 1961-960X

Éditeur :

CNRS (UMR 7528 Mondes iraniens et indiens), Éditions de l'IFRI

\section{Édition imprimée}

Date de publication : 1 décembre 2013

ISSN : 0240-8910

\section{Référence électronique}

Laetitia Nanquette (Bif), « Mansour Bonakdarian. Iranian Studies in the United Kingdom in the Twentieth Century ", Abstracta Iranica [En ligne], Volume 32-33| 2013, document 434, mis en ligne le 01 juillet 2016, consulté le 29 septembre 2020. URL : http://journals.openedition.org/abstractairanica/ 40969 ; DOI : https://doi.org/10.4000/abstractairanica.40969

Ce document a été généré automatiquement le 29 septembre 2020

Tous droits réservés 


\title{
Mansour Bonakdarian. Iranian Studies in the United Kingdom in the Twentieth Century
}

\author{
Laetitia Nanquette (Bif)
}

\section{RÉFÉRENCE}

Mansour Bonakdarian. «Iranian Studies in the United Kingdom in the Twentieth

Century ». Iranian Studies 43, no. 3, 2010, p. 265-293.

Ce long article sur les études iraniennes au Royaume-Uni commence par retracer l'histoire de la connaissance britannique sur l'Iran, y compris dans l'Empire britannique en Inde. L'A. analyse ensuite l'histoire complexe de ce qui deviendra les études iraniennes et commence par être au XXe $\mathrm{s}$. un champ des langues orientales. Il insiste sur la contribution des Iraniens à ces études, de même qu'il problématise de façon intéressante le lien entre l'enseignement des études iraniennes et l'entreprise coloniale britannique, refusant d'utiliser l'orientalisme saïdien comme cadre d'analyse. L'A. étudie également l'apport des contributions non-universitaires sur l'Iran, le financement des études iraniennes et fait des incursions en Irlande et en Inde, soulignant les limitations d'une étude circonscrite au territoire national britannique et à un $\mathrm{XX}^{\mathrm{e}} \mathrm{s}$. aux contours mouvants. Il s'agit en définitive d'un article très dense, parfois confus car abordant des sujets hétérogènes, mais qui complémente parfaitement la recherche déjà disponible à ce sujet. 


\section{AUTEURS}

LAETITIA NANQUETTE (BIF)

Paris 